\title{
Geoscięcences
}

\section{Application of the fundamental parameter method to the assessment of major and trace elements in soil and sediments from Osamu Utsumi uranium mine by WDXRF}

Sabine Neusatz Guilhen ${ }^{1,2}$

https://orcid.org/0000-0003-2604-1225

Marycel Elena Barboza Cotrim ${ }^{1,3}$

https://orcid.org/0000-0002-6462-4758

Solange Kazumi Sakata ${ }^{1,4}$

https://orcid.org/0000-0001-6072-5853

Marcos Antônio Scapin ${ }^{1,5}$

https://orcid.org/0000-0002-0606-4369

IInstituto de Pesquisas Energéticas e Nucleares, São Paulo - São Paulo - Brasil.

E-mails: ${ }^{2}$ snguilhen@ipen.br, ${ }^{3}$ mecotrim@ipen.br, sksakata@ipen.br, ${ }^{5}$ mascapin@ipen.br

\section{Abstract}

Wavelength dispersive X-ray fluorescence spectrometry (WDXRF) is a suitable technique for the characterization of contaminated mining sites, providing a quick and reliable screening for areas of significant contamination. This study established and validated a non-destructive methodology for quantitative simultaneous determination of major and minor constituents in soil and sediments by WDXRF, which was further applied to quantify soil and sediment samples from Osamu Utsumi uranium mine (Caldas, Minas Gerais, Brazil). Elements such as $\mathrm{Ce}, \mathrm{La}, \mathrm{Nd}, \mathrm{Mn}$ and $\mathrm{U}$ were found in more concentrated levels in the calcium diuranate deposit (DUCA), whereas Fe and $\mathrm{Al}$ were found at higher levels in the soil samples corresponding to sites where accentuated leaching processes have occurred. Comparatively, the levels of $U$ and rare-earth elements were found in significantly higher levels in the sediments retrieved from the mine's pit as a result of acid mine drainage. These findings are believed to be useful as an initial environmental assessment for the decommissioning process of the mine.

Keywords: WDXRF spectrometry; fundamental parameter method; validation; uranium mine, soil and sediment. 


\section{Introduction}

Acid mine drainage (AMD), one of the most serious problems resulting from mining industrial activities, results from the oxidation of sulfide minerals present in the wastes [Doyle, 1990; Sima et al., 2011]. This process releases $\mathrm{H}^{+}$ions, lowering the $\mathrm{pH}$ and creating conditions under which metals can be leached [Blodau, 2006]. The effluent produced during this process contains dissolved metals in sulfuric acid [Fraenkel et al., 1985]. The acidic environment favors the solubilization of radionuclides (uranium and thorium) and stable elements (such as manganese, iron, zinc, fluoride, etc.), increasing these elements' concentration to levels that may exceed legal limits for direct launching into the environment. Therefore, the plants and cover crops' growth get inhibited, causing erosion of the soil and an imminent contamination threat to streams and aquifers [Lyew \& Shepard, 1997; Nóbrega et al., 2008], since the chemical elements originated from the acid mine drainage (AMD) can spread up to hundreds of kilometers from the mining area. The effects can linger on for long periods of time, even after the cessation of mining activities [Salomons, 1995; Borma \& Soares, 2002].

The first uranium mining-industrial complex in Brazil was located on the plateau of Poços de Caldas (Minas Gerais, Brazil) under the name of "Osamu Utsumi". The complex (CIPC) consists of an open pit mine, an ore

\section{Experiment}

\section{Sampling}

Soil and sediment sampling were conducted by technicians of the $\mathrm{Nu}$ clear and Energy Research Institute (IPEN/CNEN-SP) and INB throughout different specific sites of the minecomplex. All sampling sites are within the mine area and represent locations believed to be the most impacted by mining activities.

Surface soil samples were collected

\section{Sample preparation}

Soil and sediment samples were subjected to oven drying at $105 \pm 5^{\circ} \mathrm{C}$, according to the certificate supplied with NIST's standard reference material 2709a crushing facility and a grinding plant for chemical processing [Fernandes et al., 1995]. The Brazilian Nuclear Industries (INB) had control of the operations in the mine, which initiated back in 1982 and lasted until the year of 1995 . Approximately 44.56 million $\mathrm{m}^{3}$ of mining waste was generated during this period. This waste was disposed of in stacks over large areas surrounding the mining site, called "waste dumps" and "tailings beach". Since, 1998, mining and milling activities take place in Caetité (Bahia, Brazil). In 2004, INB signed an agreement to prepare and present a decommissioning plan in order to fulfil the requirements imposed by the Brazilian Institute of Environment and Renewable Natural Resources (IBAMA) and the National Nuclear Energy Commission (CNEN) requirements, both regulatory bodies in Brazil concerning environmental and nuclear resources, respectively. Because of this, actions have been taken to minimize the environmental impact such as: neutralization of the drained water (accumulated in the pit as a result of the AMD) and coating of the sterile heaps surface and waste rock piles with a $30 \mathrm{~cm}$ layer of compact clay in order to avoid rain water percolation through the piles [Cunha et al., 2007].

Because of the extremely low $\mathrm{pH}$ of the water in the mine's pit, a chemical treatment is being executed using calcium hydroxide, generating a dark alkaline sludge known as "DUCA" (calcium diuranate), which has been deposited in the pit's borders for over 20 years and is mostly covered with acidic water now [Fagundes, 2005; Ferrari, 2010; Gomes \& Ladeira, 2011]. After closing operations, water has been accumulating at the bottom of the mine over the years, covering the deposited DUCA.

Several studies were initiated in the attempt to support a safe and responsible closure of the mine, by monitoring the area and proposing alternatives for its remediation. In this context, this study aims to establish and validate a non-destructive quantitative chemical analysis methodology for simultaneous determination of major and minor constituents in soil and sediments from Osamu Utsumi uranium mine and vicinities by wavelength dispersive X-ray fluorescence spectrometry (WDXRF). Fast, accurate and easy to use, this technique requires a relatively simple sample preparation, allowing multi-element, non-destructive, analysis in a wide range of concentrations [Ma et al., 2001]. Several papers describe the $\mathrm{XRF}$ technique as the most accepted analytical method for mineral analysis [Kodom et al., 2012; Ene et al.; 2010; Melquiades et al., 2009; Davidson, 2012]. Many mining industries and service laboratories employ this technique for its ease of operation, discrimination and quality and control of the exploration process [Ekinci et al., 2016]. from different sites of the pit's surroundings and waste dumps (locally called "bota-fora" or "BF") using a stainlesssteel scoop, after carefully removing the top layer of soil and debris to a desired sample depth of $10-20 \mathrm{~cm}$.

One of the sediment samples was collected from the calcium diuranate deposit (DUCA), while three others were collected from the bottom of the pit's

- San Joaquin Soil (New Brunswick, USA). Each sample was crushed and homogenized in an agate mortar in order to obtain particle sizes between 74 and lake, using a Van Veen grab sampler. The site and location of each sample is shown in Table 1.

Each sample was placed into sterile labeled polypropylene bags and sealed hermetically for transportation to IPEN's Chemical and Environmental Analysis Laboratory (LAQA) at the Center for Chemistry and Environment (IPEN/CNEN-SP).

$105 \mu \mathrm{m}$. Approximately $2.0 \mathrm{~g}$ of each sample was pressed into a $25.00 \pm 0.01$ $\mathrm{mm}$ diameter and $5.0 \pm 0.2 \mathrm{~mm}$ thick disc using a hydraulic press and applying 
a pressure of $20 \mathrm{MPa} .2 \mathrm{~s}^{-1}$ on a boric

\section{Instrumental parameters}

The experiments were carried out using a RIGAKU Co (Tokyo, Japan) wavelength dispersive X-ray fluorescence spectrometer, model RIX 3000 with a Rh-anode X-ray tube, a $75 \mu \mathrm{m}$ Be window,

\section{Fundamental parameter method}

The fundamental parameter (FP) method was applied for the quantitative determination using the 2 theta scan mode of the spectrometer's software. This method employs mathematical algorithms to correct inter-element of coexisting elements (absorption and enhancement of X-rays and overlap of peaks) through the measure of the intensity of each element's emission line and the tabulated values of the main fundamental parameters, such as the primary spectral distribution (source), the photoelectric and the mass absorption coefficients, fluorescence yields and others [Lachance \& Fernand, 1994; Scapin et al., 2011].

Quantitative analyzes performed through the FP method do not necessarily require the usage of certified reference materials. However, the reliability increases when the parameters that make up the mathematical expression are obtained by appropriate and trace-

\section{Methodology evaluation}

The methodology was validated in terms of precision and accuracy through statistical tests suggested by INMETRO's document DOQ-CGCRE-008 [Inmetro, 2011]. The data were ob-

Where $X_{i}$ is a measured value, $\bar{X}$ is the average value, $K_{n}$ is the Chauvenet's coefficient and $s$ is the standard deviation.

Where, $C_{m}$ is the measured value, $\bar{C}$ is the average value and $n$ is the number of replicates. acid $\left(\mathrm{H}_{3} \mathrm{BO}_{3}\right.$ P.A.) basis, which had been

a $60 \mathrm{kV}$ maximum acceleration voltage generator, a $\mathrm{NaI}(\mathrm{Tl})$ scintillation detector and a gas-flow proportional counter. The fundamental parameters (FP) method was applied for correction of the absorption/

able standards. The calculations involve two underlying steps: calibration and prediction.

In the calibration step, the FP equation is employed to predict the characteristic intensities of the calibration standards' emission lines. The calculations are performed specifically for the instrument through which the measurements are obtained, since the PF's equation considers geometry aspects, source and instrumental conditions.

The calibration takes into consideration the theoretically calculated intensities and the measured intensities, which are corrected for each characteristic line. This correction is acquired through the angular coefficient, experimental net intensities versus the calculated relative intensities, which correspond to the proportional factor used in the correction [Natgaa \& Bueno, 2001].

In the predicting step, it is neces-

tained for 3 replicates of each sample and 7 measurements for each replicate, adding up to a set of 21 measurements for each element of NIST's standard reference material, SRM 2709a, San

$$
\left|X_{i}-\bar{X}\right|>K_{n}^{*} s
$$

The limit of quantification (LoQ) for the certified elements was calculated for a $95 \%$ confidence level, according

$$
L o Q=2 * \sqrt{\frac{\sum_{m=1}^{n}\left(C_{m}-\bar{C}\right)^{2}}{n-1}}
$$

The precision was evaluated through the relative standard deviation (\%RSD) and the acceptability was verified using previously compressed at $100 \mathrm{MPa} .2 \mathrm{~s}^{-1}$.

excitation effects. The parameters such as excitation, emission line, divergence slit, diffracting crystal, type of detector, scan counting time, and Bragg's positions are shown in Table 2.

sary to estimate the approximate composition of the sample first. Typically, the detected emission lines' relative intensity corresponding to each element in the matrix is considered, assuming that the total emission pertains to a composition of $100 \%$ (or another total value, if the minor constituents are ignored [Natgaa \& Bueno, 2001].

From this equation, the intensities that should be observed for the assumed composition are software-calculated. They are compared to the measured values, then the assumed composition is adjusted and a new set of expected intensities is calculated. This interaction process is automatically repeated until the assumed composition provides an $\mathrm{X}$-ray intensity that corresponds to the measured value at a significance level of 0.05 . The composition that successfully meets this relationship becomes the result of the analysis [Natgaa \& Bueno, 2001; Scapin, 2015].

\section{Joaquin Solo.}

The Chauvenet test was applied for the detection of the outliers, Eq. 1 [Scapin, 2003].

to Eq. 2 [Rousseau, 2001].

the equation of Horwitz, in which the HorRat's $\left(\mathrm{HO}_{\mathrm{R}}\right)$ values fit more accordingly as per Eq. 3 [Inmetro, 2011].

$$
H O_{R}=\frac{R S D \%_{\text {experiental }}}{R S D \%_{\text {Horwitz }}}
$$


The accuracy was evaluated through the Z-score test, according to Eq. 4 [Inmetro, 2011].

$$
Z=\frac{\left(\bar{X}_{L a b}-\bar{X}_{C R M}\right)}{\sqrt{U_{L a b}^{2}+U_{C R M}^{2}}}
$$

Where, $Z$ is the test value, $\bar{X}_{\text {Lab }}$ is the experimental average, $U_{\text {Lab }}^{2}$ is the CRM's true

value, $\bar{X}_{C R M}$ is the experimental variance and $U_{C R M}^{2}$ is the variance obtained for the CRM.

\section{Results and discussion}

\section{Quality Control}

The results obtained for NIST's certified reference material, SRM 2709, showed that the method's precision
( $\mathrm{RSD} \%, \mathrm{n}=7)$ ranged from 1.5 to $6.7 \%$ (Table 1). Since the calculated values for all the elements are below

\begin{tabular}{|c|c|c|c|c|c|c|c|}
\hline Elements & Xcert $\pm \sigma$ & Xdeter $\pm \sigma$ & RSD \% & $\mathrm{HO}_{\mathrm{R}}$ & RE \% & $\mathbf{Z}$ & LoQ \\
\hline $\mathrm{Na}(\%)$ & $1.16 \pm 0.03$ & $1.09 \pm 0.02$ & 1.8 & 0.9 & 6.2 & -2.0 & 0.04 \\
\hline $\operatorname{Mg}(\%)$ & $1.51 \pm 0.05$ & $1.63 \pm 0.04$ & 2.5 & 1.3 & -8.1 & 2.0 & 0.07 \\
\hline $\mathrm{Al}(\%)$ & $7.50 \pm 0.06$ & $7.7 \pm 0.2$ & 2.6 & 1.3 & 2.8 & 1.1 & 0.4 \\
\hline Si (\%) & $29.66 \pm 0.23$ & $29.2 \pm 0.6$ & 2.1 & 1.1 & 1.6 & -0.7 & 1.2 \\
\hline$P\left(\mu g g^{-1}\right)$ & $620 \pm 50$ & $700 \pm 20$ & 2.9 & 1.5 & -12.3 & 1.5 & 32 \\
\hline $\mathrm{S}\left(\mu \mathrm{gg}^{-1}\right)$ & $890 \pm 20$ & $940 \pm 30$ & 3.2 & 1.6 & -5.1 & 1.3 & 54 \\
\hline $\mathrm{K}(\%)$ & $2.03 \pm 0.06$ & $2.13 \pm 0.07$ & 3.3 & 1.7 & -4.9 & 1.0 & 0.15 \\
\hline $\mathrm{Ca}(\%)$ & $1.89 \pm 0.05$ & $1.95 \pm 0.03$ & 1.5 & 0.8 & -3.4 & 1.1 & 0.05 \\
\hline $\mathrm{Ti}(\%)$ & $0.342 \pm 0.024$ & $0.34 \pm 0.01$ & 2.9 & 1.5 & 1.7 & -0.2 & 0.03 \\
\hline $\mathrm{Fe}(\%)$ & $3.5 \pm 0.1$ & $3.4 \pm 0.1$ & 2.9 & 1.5 & 1.7 & -0.5 & 0.1 \\
\hline$V\left(\mu g^{-1}\right)$ & $112 \pm 5$ & $101 \pm 5$ & 5.0 & 1.3 & 9.7 & -1.5 & 11 \\
\hline $\mathrm{Cr}\left(\mu \mathrm{g} \mathrm{g} \mathrm{g}^{-1}\right)$ & $130 \pm 4$ & $142 \pm 5$ & 3.5 & 0.9 & -8.9 & 1.8 & 10 \\
\hline $\operatorname{Mn}\left(\mu g g^{-1}\right)$ & $538 \pm 17$ & $535 \pm 36$ & 6.7 & 1.7 & 0.6 & -0.1 & 73 \\
\hline $\mathrm{Ni}\left(\mu \mathrm{g} \mathrm{g}^{-1}\right)$ & $88 \pm 5$ & $95 \pm 4$ & 4.2 & 1.1 & -7.4 & 1.0 & 8 \\
\hline $\mathrm{Cu}\left(\mu \mathrm{g} \mathrm{g}^{-1}\right)$ & $34.6 \pm 0.7$ & $37 \pm 2$ & 5.4 & 1.4 & -8.1 & 1.3 & 4 \\
\hline $\mathrm{Zn}\left(\mu \mathrm{g} \mathrm{g}^{-1}\right)$ & $106 \pm 3$ & $104 \pm 7$ & 6.7 & 1.7 & 1.7 & -0.2 & 14 \\
\hline${ }^{*} \mathrm{Rb}\left(\mu \mathrm{g} \mathrm{g}^{-1}\right)$ & 96 & $85 \pm 3$ & 3.5 & 0.9 & 11.8 & $* * *$ & 6 \\
\hline $\operatorname{Sr}\left(\mu g g^{-1}\right)$ & $231 \pm 2$ & $230 \pm 10$ & 4.3 & 1.1 & 0.4 & -0.1 & 19 \\
\hline${ }^{*} \operatorname{Zr}\left(\mu \mathrm{g} \mathrm{g}^{-1}\right)$ & 160 & $177 \pm 8$ & 4.5 & 1.1 & -10.8 & $* * *$ & 15 \\
\hline $\mathrm{Ba}\left(\mu \mathrm{g} \mathrm{g}^{-1}\right)$ & $968 \pm 40$ & $99 \pm 044$ & 4.4 & 1.1 & -2.3 & 0.4 & 88 \\
\hline $\mathrm{Pb}\left(\mu \mathrm{g} \mathrm{g}^{-1}\right)$ & $18.9 \pm 0.5$ & $18 \pm 1$ & 5.6 & 1.4 & 2.4 & -0.5 & 2 \\
\hline
\end{tabular}

*Noncertified values

The accuracy was evaluated in terms of relative error $(\mathrm{RE} \%)$, which ranged from 0.4 to $12.3 \%$. The acceptability of these values, assessed using the $\mathrm{Z}$-score test, showed that the calculated values for all elements are $\leq 2$, indicating that the obtained results are in good agreement with the certified values [Inmetro, 2011]. The limits of quantification calculated for the major constituents ranged from $0.04(\mathrm{Na})$ to $1.2 \%(\mathrm{Si})$ and, for the minor constituents, from $2(\mathrm{~Pb})$ to $73 \mu \mathrm{g} \mathrm{g}^{-1}(\mathrm{Mn})$.
2 , the method generated results with satisfactory precision [Inmetro, 2011].
Table 1

SRM 2709's certified and determined values, RSD\%, $\mathrm{HO}_{\mathrm{R}}, \mathrm{RE} \%$, LoQ, and Z-score.

Finally, the results show that the proposed methodology is statistically suitable and, therefore, satisfactory for the determination of major and minor constituents in soil and sediment samples, as well as similar matrices. 


\section{Soil samples}

The results of the WDXRF analysis for the soil samples collected at Osamu Utsumi mine are presented in Table 2.

Table 2

WDXRF analysis for soil samples from Osamu Utsumi mine.

\begin{tabular}{|c|c|c|c|c|c|c|c|c|c|}
\hline Element (\%) & Soil 1 & Soil 2 & Soil 3 & Soil 4 & Soil 5 & Soil 6 & Soil 7 & Soil 8 & Soil 9 \\
\hline $\mathrm{Al}$ & $10 \pm 1$ & $20 \pm 1$ & $12 \pm 1$ & $13 \pm 1$ & $14 \pm 1$ & $14 \pm 1$ & $14 \pm 1$ & $5.7 \pm 0.6$ & $11 \pm 1$ \\
\hline $\mathrm{Fe}$ & $26 \pm 1$ & $5.0 \pm 0.5$ & $6.8 \pm 0.7$ & $5.3 \pm 0.5$ & $5.2 \pm 0.5$ & $6.6 \pm 0.7$ & 0.002 & 0,555 & $24 \pm 1$ \\
\hline K & $3.4 \pm 0.3$ & $2.7 \pm 0.3$ & $10 \pm 1$ & $11 \pm 1$ & $9.4 \pm 0.9$ & $10 \pm 1$ & $11 \pm 1$ & 0,013 & $3.2 \pm 0.3$ \\
\hline $\mathrm{Si}$ & $7.2 \pm 0.7$ & $16 \pm 1$ & $21 \pm 1$ & $21 \pm 1$ & $21 \pm 1$ & $21 \pm 1$ & $23 \pm 1$ & $1.0 \pm 0.1$ & $9.3 \pm 0.9$ \\
\hline Element $\left(\mu \mathrm{g} \mathrm{g}^{-1}\right)$ & Soil 1 & Soil 2 & Soil 3 & Soil 4 & Soil 5 & Soil 6 & Soil 7 & Soil 8 & Soil 9 \\
\hline $\mathrm{Ca}$ & $39 \pm 4$ & $4 \pm 1$ & $17 \pm 2$ & $15 \pm 2$ & $6 \pm 1$ & $22 \pm 2$ & $24 \pm 2$ & $25 \pm 1$ & $312 \pm 31$ \\
\hline S & $2800 \pm 300$ & $12 \pm 1$ & $689 \pm 70$ & $364 \pm 36$ & $113 \pm 11$ & $19 \pm 2$ & $850 \pm 85$ & $6.3 \pm 0.6$ & $934 \pm 93$ \\
\hline $\mathrm{Mn}$ & $258 \pm 30$ & $44 \pm 4$ & $23 \pm 2$ & $27 \pm 3$ & $115 \pm 12$ & $206 \pm 21$ & $7 \pm 1$ & 2900 & $70 \pm 7$ \\
\hline $\mathrm{Ti}$ & $291 \pm 30$ & $496 \pm 50$ & $508 \pm 51$ & $490 \pm 49$ & $582 \pm 60$ & $490 \pm 49$ & $431 \pm 43$ & $10 \pm 1$ & $284 \pm 98$ \\
\hline $\mathrm{Mg}$ & $28 \pm 3$ & $87 \pm 9$ & $72 \pm 7$ & $94 \pm 9$ & $65 \pm 7$ & $70 \pm 7$ & $37 \pm 4$ & $787 \pm 79$ & $35 \pm 4$ \\
\hline $\mathrm{Na}$ & $18 \pm 2$ & $4 \pm 1$ & 84d` 8 & $69 \pm 7$ & $88 \pm 9$ & $57 \pm 6$ & $57 \pm 6$ & ND & $19 \pm 2$ \\
\hline $\mathrm{Nb}$ & $6 \pm 1$ & $6 \pm 1$ & $5 \pm 1$ & $5 \pm 1$ & $6 \pm 1$ & $6 \pm 1$ & $5 \pm 1$ & $2 \pm 1$ & $4 \pm 1$ \\
\hline $\mathrm{Ni}$ & $18 \pm 1$ & $3 \pm 1$ & $3 \pm 1$ & $2 \pm 1$ & $2 \pm 1$ & $7 \pm 1$ & $4 \pm 1$ & $2 \pm 1$ & $19 \pm 2$ \\
\hline$P$ & $44 \pm 4$ & $34 \pm 3$ & $168 \pm 17$ & $181 \pm 18$ & $68 \pm 7$ & $197 \pm 20$ & $186 \pm 19$ & $25 \pm 3$ & $74 \pm 7$ \\
\hline $\mathrm{Pb}$ & $21 \pm 2$ & $11 \pm 1$ & $45 \pm 5$ & $33 \pm 3$ & $8 \pm 1$ & $14 \pm 1$ & $24 \pm 2$ & $2 \pm 1$ & $17 \pm 2$ \\
\hline $\mathrm{Sr}$ & $28 \pm 3$ & $6 \pm 1$ & $52 \pm 5$ & $46 \pm 5$ & $19 \pm 2$ & $63 \pm 6$ & $44 \pm 4$ & $54 \pm 5$ & $18 \pm 2$ \\
\hline Th & $52 \pm 5$ & $13 \pm 1$ & $15 \pm 2$ & $19 \pm 2$ & $11 \pm 1$ & $23 \pm 2$ & $23 \pm 2$ & $11 \pm 1$ & $77 \pm 8$ \\
\hline V & $28 \pm 3$ & $30 \pm 3$ & $57 \pm 6$ & $45 \pm 5$ & $36 \pm 4$ & $61 \pm 6$ & $47 \pm 5$ & $5 \pm 1$ & $14 \pm 1$ \\
\hline $\mathrm{Zn}$ & $134 \pm 13$ & $13 \pm 1$ & $17 \pm 2$ & $18 \pm 2$ & $7 \pm 1$ & $29 \pm 3$ & $4 \pm 1$ & $398 \pm 40$ & $193 \pm 19$ \\
\hline $\mathrm{Zr}$ & $249 \pm 30$ & $343 \pm 30$ & $327 \pm 33$ & $380 \pm 38$ & $191 \pm 19$ & $724 \pm 72$ & $775 \pm 78$ & ND & $46 \pm 5$ \\
\hline$U$ & $58 \pm 6$ & $4 \pm 1$ & $17 \pm 2$ & $20 \pm 2$ & $13 \pm 1$ & $40 \pm 4$ & $22 \pm 2$ & $245 \pm 30$ & $157 \pm 16$ \\
\hline $\mathrm{Ce}$ & $80 \pm 8$ & $25 \pm 3$ & $101 \pm 10$ & $159 \pm 16$ & $98 \pm 10$ & $236 \pm 24$ & $238 \pm 24$ & 1200 & $291 \pm 29$ \\
\hline La & $51 \pm 5$ & $60 \pm 6$ & $113 \pm 11$ & $111 \pm 10$ & $59 \pm 6$ & $148 \pm 15$ & $208 \pm 21$ & 1500 & $335 \pm 34$ \\
\hline $\mathrm{Nd}$ & $27 \pm 3$ & $4 \pm 1$ & $23 \pm 2$ & $19 \pm 2$ & $27 \pm 3$ & $80 \pm 8$ & $95 \pm 9$ & $433 \pm 43$ & $115 \pm 12$ \\
\hline $\operatorname{Pr}$ & $9 \pm 1$ & $24 \pm 2$ & $7 \pm 1$ & $39 \pm 4$ & $20 \pm 2$ & $6 \pm 1$ & $14 \pm 1$ & $130 \pm 13$ & $33 \pm 3$ \\
\hline $\mathrm{Sm}$ & ND & $2 \pm 1$ & $10 \pm 1$ & $11 \pm 1$ & $13 \pm 1$ & $6 \pm 1$ & $19 \pm 2$ & $31 \pm 3$ & ND \\
\hline Y & $9 \pm 1$ & $4 \pm 1$ & $9 \pm 1$ & $10 \pm 1$ & $5 \pm 1$ & $13 \pm 1$ & $12 \pm 1$ & $52 \pm 5$ & $19 \pm 2$ \\
\hline
\end{tabular}

The analysis revealed that the samples 2, 3, 4, 5, 6 and 7 are constituted predominantly of Si (approx. 15-23\%) and Al (approx. 12-20\%). According to Table $\mathrm{S} 1$, this group of samples was collected from the waste dump, showing some consistency with each other regarding their major constituents.

$\mathrm{Fe}$ and $\mathrm{Al}$ are the main elements present in samples 1 and 9, evidencing a similarity between the sample collected from the mine's pit (Soil 1) and the one collected in TRINE-3 (Soil 9). This signals for accentuated leaching processes occurring in these sampling sites, once the Fe concentrations ranges $24-26 \%$ in composition.

$\mathrm{Ca}$ is found as the main constituent of the matrix in sample 8 (approx. 25\%), which is consistent to the nature of the sample. According to Table S1, "Soil 8" was collected from a calcium diuranate deposit (DUCA), resulting from the treatment of the acidic waters from the mine's pit.

The highest amounts of $\mathrm{Ce}, \mathrm{La}$ and $\mathrm{Nd}$ are found in "Soil 8", showing that these elements tend to concentrate in the DUCA deposit as a result of the neutralization process applied to the acidic pit water. Ce concentration in "Soil 8" $\left(1200 \mu \mathrm{g} \mathrm{g}^{-1}\right)$ is up to 48 times higher than in "Soil 2", the sample which presented the lowest amount of this element $\left(25 \mu \mathrm{g} \mathrm{g}^{-1}\right)$. The average Ce concentration for samples 1 ,
$2,3,4,5,6,7$ and 9 was of $153.5 \mu \mathrm{g} \mathrm{g}^{-1}$.

The concentration of La found in "Soil 8" was of $1500 \mu \mathrm{g} \mathrm{g}^{-1}$, whereas the average concentration found for the remainder of the samples was $135.6 \mu \mathrm{g} \mathrm{g}^{-1}$. For Nd, the average concentration for all samples, except "Soil 8", was $46.5 \mu \mathrm{g} \mathrm{g}^{-1}$, while "Soil 8 " registered a $433 \mu \mathrm{g} \mathrm{g} \mathrm{g}^{-1}$ concentration, i.e., approximately 10 times higher.

$\mathrm{U}$ was found in comparably higher concentrations in samples 8 and 9 (above $100 \mu \mathrm{g} \mathrm{g}^{-1}$ ), while Soil 8 presents the highest concentration of $\mathrm{Mn}\left(2,900 \mu \mathrm{g} \mathrm{g}^{-1}\right)$ among the studied samples, supporting the fact that some elements may be concentrated in the DUCA deposit. 


\section{Sediment samples}

The results obtained by WDXRF analysis for the sediment samples from

Osamu Utsumi mine are presented in Table 3.

\begin{tabular}{|c|c|c|c|c|}
\hline Element & Sediment 1 & Sediment 2 & Sediment 3 & Sediment 4 \\
\hline $\mathrm{Al}$ & $4.6 \pm 0.5$ & $12 \pm 1$ & $11 \pm 1$ & $4.8 \pm 0.5$ \\
\hline $\mathrm{Fe}$ & $0.349 \pm 0.035$ & $4.6 \pm 0.5$ & $6.1 \pm 0.6$ & $0.552 \pm 0.055$ \\
\hline K & $0.025 \pm 0.003$ & $1.0 \pm 0.1$ & $0.204 \pm 0.020$ & $0.033 \pm 0.003$ \\
\hline $\mathrm{Si}$ & $1.2 \pm 0.1$ & $3.7 \pm 0.4$ & $1.9 \pm 0.2$ & $1.0 \pm 0.1$ \\
\hline $\mathrm{Ca}$ & $23 \pm 1$ & $9.3 \pm 0.9$ & $7.5 \pm 0.8$ & $24 \pm 1$ \\
\hline $\mathrm{Mn}$ & $5.5 \pm 0.6$ & $4.5 \pm 0.5$ & $3.2 \pm 0.3$ & $4.4 \pm 0.4$ \\
\hline $\mathrm{Mg}$ & $1.8 \pm 0.2$ & $2.5 \pm 0.3$ & $2.7 \pm 0.3$ & $1.5 \pm 0.2$ \\
\hline Element & Sediment 1 & Sediment 2 & Sediment 3 & Sediment 4 \\
\hline $\mathrm{Ti}$ & $11 \pm 1$ & $37 \pm 4$ & $56 \pm 6$ & $9 \pm 1$ \\
\hline $\mathrm{Na}$ & $23 \pm 2$ & $67 \pm 7$ & $67 \pm 7$ & $22 \pm 2$ \\
\hline $\mathrm{Nb}$ & $2 \pm 1$ & $5 \pm 1$ & $5 \pm 1$ & ND \\
\hline $\mathrm{Ni}$ & $8 \pm 1$ & $14 \pm 1$ & $15 \pm 2$ & $3 \pm 1$ \\
\hline $\mathrm{P}$ & $24 \pm 2$ & $99 \pm 10$ & $101 \pm 10$ & $24 \pm 2$ \\
\hline $\mathrm{Pb}$ & $5 \pm 1$ & $8 \pm 1$ & $6 \pm 1$ & $2 \pm 1$ \\
\hline $\mathrm{Sr}$ & $40 \pm 4$ & $91 \pm 9$ & $68 \pm 7$ & $38 \pm 4$ \\
\hline Th & $9 \pm 1$ & $20 \pm 2$ & $20 \pm 2$ & $7 \pm 1$ \\
\hline $\mathrm{Zn}$ & $518 \pm 52$ & $803 \pm 80$ & $841 \pm 84$ & $490 \pm 49$ \\
\hline $\mathrm{Zr}$ & ND & $5 \pm 1$ & $2 \pm 1$ & ND \\
\hline$U$ & $268 \pm 27$ & $488 \pm 49$ & $295 \pm 30$ & $283 \pm .28$ \\
\hline $\mathrm{Ce}$ & $1.3 \pm 0.1$ & $1.1 \pm 0.1$ & $897 \pm 90$ & $1.2 \pm 0.1$ \\
\hline La & $1.6 \pm 0.2$ & $2.2 \pm 0.2$ & $2.3 \pm 0.2$ & $1.6 \pm 0.2$ \\
\hline $\mathrm{Nd}$ & $446 \pm 45$ & $751 \pm 75$ & $577 \pm 58)$ & $483 \pm 48$ \\
\hline $\operatorname{Pr}$ & $184 \pm 18$ & $217 \pm 22$ & $240 \pm 24$ & $178 \pm 18$ \\
\hline $\mathrm{Sm}$ & $17 \pm 2$ & $33 \pm 3$ & $31 \pm 3$ & $30 \pm 3$ \\
\hline $\mathrm{Y}$ & $47 \pm 5$ & $85 \pm 9$ & $130 \pm 13$ & $56 \pm 6$ \\
\hline
\end{tabular}

Samples 1 and 4 present $\mathrm{Ca}$ as the main constituent $(23 \%$ and $24 \%$, respectively), indicating that "Sediment 4", which was collected from the site designated as "Mine Pit-3", has a chemical similarity to the sample "Sediment 1 ", corresponding to the calcium diuranate (DUCA). Due to neutralization processes of the acid drainage water, calcium diuranate precipitates and is placed in the pit's borders (as DUCA). Leaching processes dilute some of the calcium, which is drained back to the mine's pit and further precipitates as $\mathrm{CaCO}_{3}$. This explains the elevated calcium levels in sample 4.

This concentration process might constitute a potential challenge to the decommissioning of the mine, since some elements may be resolubilized and, thus, concentrated in the pit water by acid leaching occurring in the DUCA deposit. This, in turn, could potentially become a magnification cycle, increasing the availability of these elements in the mine, since the water will be treated again by neutralization processes and be deposited as calcium diuranate, which will undergo further leaching and resolubilization and so on.

Samples 2 and 3 exhibit a matrix composed of mostly $\mathrm{Al}, \mathrm{Ca}$ and Fe. They were both collected from inside the mine's pit. Fe is significantly higher in these samples $(4.6 \%$ for "Sediment 2 " and $6.1 \%$ for "Sediment 3 "), compared to samples 1 and $4(0.35 \%$ and $0.55 \%$, respectively), most probably because of the leaching process that happens in the pit's surroundings, which result in water
Table 3

WDXRF analysis for sediment samples from Osamu Utsumi mine.

deposits rich in solubilized Fe.

Rare-earth elements were also found in significant amounts in all sediment samples, especially Ce, La and $\mathrm{Nd}$. The concentrations are considerably higher compared to those found in the soil samples, indicating that these elements are not only prone to settle in the bottom of the pit's lake, but also concentrate over time.

Samples 1 and 4 present $U$ at an average concentration of $275 \mu \mathrm{g} \mathrm{g}^{-1}$ while in samples 2 and 3, $\mathrm{U}$ is present in an average concentration of $532 \mu \mathrm{g} \mathrm{g}^{-1}$, i.e, practically the double. $\mathrm{Mn}$ is found in high concentrations in all samples, ranging from 3,200 to $5,500 \mu \mathrm{g} \mathrm{g}^{-1}$.

Fig. 1 shows the comparative distribution of rare-earth elements among the soil and the sediment samples. 

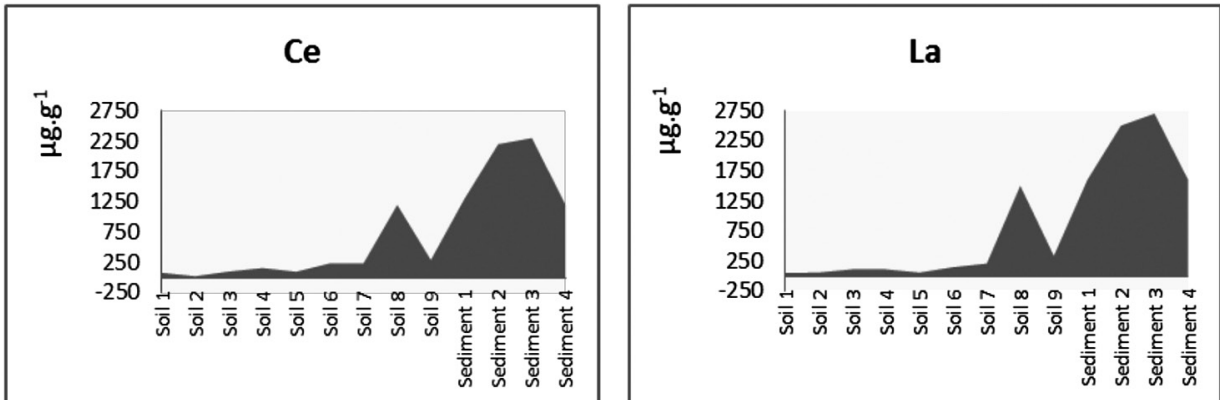

Figure 1

Distribution of rare-earth elements among soil and sediment samples.

Fig. 2 shows the comparative distribution of uranium among the soil and

Figure 2

Distribution of uranium among soil and sediment samples.

From Figures 1 and 2, it becomes evident that $U$ and rare-earth elements are likely to concentrate in the sediment. This probably occurs because of the solubilization of these elements where the tailings are stored, promoted by the acid mine drainage (AMD). The solubilized elements accumulate in the acidic water and further end up depositing in the mine's pit lake bottom sediments.

Taking this under consideration,

\section{Conclusions}

The quantitative determination of major and minor constituents in soil and sediments from Osamu Utsumi uranium mine was successfully carried out by the WDXRF technique using the fundamental parameter method. This methodology was validated in agree-
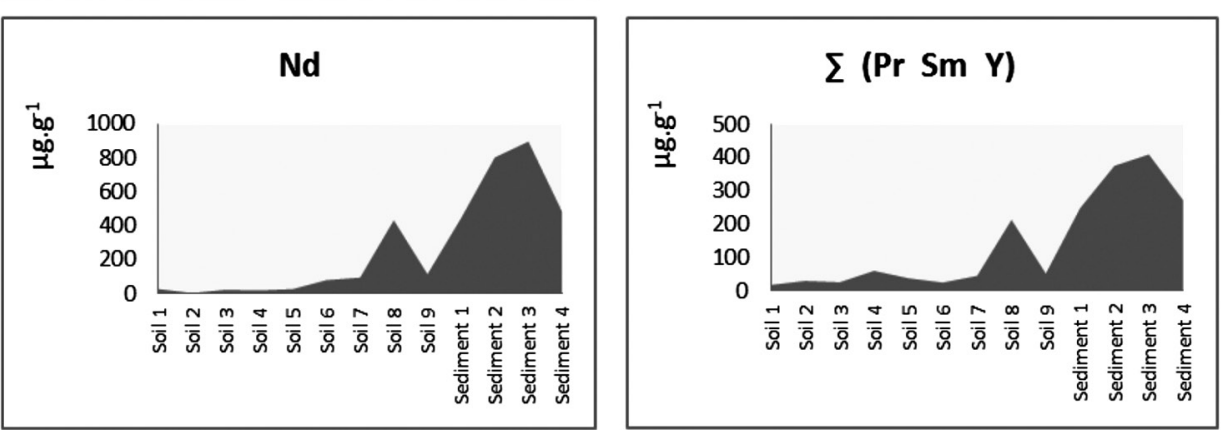

the sediment samples. $U$ is considered a monitoring element of the mine's activity.

U

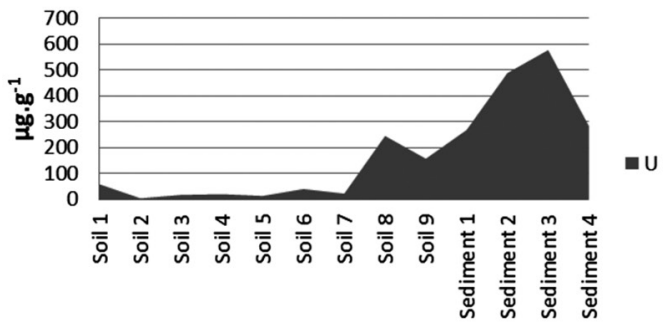

special attention should be directed to the disposal of the mining wastes and tailings throughout the mine. Acid mine drainage (AMD) promotes the resolubilization of many elements which get drained back to the pit lake. This, in turn, promotes the concentration of these elements in the water, i.e., their availability increases and they may be precipitated as calcium diuranate during neutralization of the water (one of the chemical treatments applied to the water). This precipitate is then deposited around the pit as the "DUCA" deposit. The elements present in the DUCA become susceptible for leaching again, returning to the pit water in a cyclical process.

Contaminated water in the pit lake can impact down-gradient groundwater quality. The concentration of metals and other contaminants in the pit may, through evaporation, impact migratory birds and terrestrial wildlife. ment with INMETRO's requirements using NIST's standard reference material SRM 2709, demonstrating the ability to satisfactorily produce precise and accurate results. The levels of uranium and rare-earth elements were found to be significantly higher in sediment samples than in the soil samples as a result of acid leaching processes in the pit's surroundings. These results are believed to provide an initial insight of the mechanisms occurring in the mine and how they may influence the chemical composition of the soil and sediment.

\section{References}

BLODAU, C. A review of acidity generation and consumption in acidic coal mine lakes and their watersheds. Science of the Total Environment, v. 369, p. 307-332, 2006. 
BORMA, L. S., SOARES, P. S. M. Drenagem ácida e gestão de resíduos sólidos de mineração. In: Extração de ouro: princípios, tecnologia e meio ambiente. Rio de Janeiro: CETEM/MCT, 2002. p. 253-276. (Cap. 10).

CUNHA M. F., LIMA, H. M., FLORES, J. C. C. Estado da arte do fechamento de mina em Minas Gerais. Ouro Preto: Universidade Federal de Ouro Preto, 2007. 85 p. (Dissertação de Mestrado em Engenharia Mineral).

DAVIDSON, C. M. Methods for the determination of heavy metals and metalloids in soils, p. 97-140. (Chapter 4). In: ALLOWAY, B. J. Heavy metals in soils: trace metals and metalloids in soils and their bioavailability. Reading: Springer, 2012. p. 614.

DOYLE, F. M. Acid mine drainage from sulphide ore deposits. p. 135 In: GRAY, P. M. J., BOWYER, G. J., CASTLE, J. F., VAUGHAN, D. J., WARNER, N. A. Sulphide deposits - their origin and processing. London: The Institution of Mining and Metallurgy, 1990. p. 310.

EKINCI, N., KAVAZ, E., CINAN, E., SEVINDIK, C. Elemental analysis of six mines in erzincan region using wavelength- dispersive $\mathrm{x}$-ray fluorescence spectrometry. Asian Journal of Chemistry, v. 28, n. 3, p. 489-492, 2016.

ENE, A., BOSNEAGA, A., GEORGESCU, L. Determinatuon of heavy metals in soils using XRF technique. Romanian Journal of Physics, v. 55, n. 7-8, p. 815-820, 2010.

FAGUNDES, J. R. T. Balanço hídrico do bota-fora BF4 da mina Osamu Utsumi, INB, como subsídio para projetos de remediação de drenagem ácida. Revista Brasileira de Recursos Hidricos, v. 13, p. 19-28, 2005.

FERNANDES, H. M., VEIGA, L. H. S., FRANKLIN, M. R., PRADO, V. C. S., TADDEI, J. F. Environmental impact assessment of uranium mining and milling facilities: a study case at the Pocos de Caldas uranium mining and milling site, Brazil. Journal of Geochemical Exploration, v. 52, p. 161-173, 1995.

FERRARI, C. R. Avaliação de efeitos ambientais de efluentes radioativos de mineração de urânio sobre as características físicas, químicas e diversidade da Comunidade Zooplanctônica na Unidade de Tratamento de Minérios, Represa das Antas e Represa Bortolan, Poços de Caldas (MG). São Paulo: Universidade de São Paulo, 2010. 132 p. (Dissertação de Mestrado em Engenharia Mineral).

FRAENKEL, M. O., SANTOS R. C., LOURENÇO, F. E. V. L., MUNIZ, W. S. Jazida de urânio do Planalto Poços de Caldas, Minas Gerais. In: SCHOBBENHAUS, C., COELHO, C. E. S. Principais Depósitos Minerais do Brasil. Brasília: DNPM/ CVRD, 1985. v. 1, p. 89-103.

GOMES, A. F. S., LADEIRA, A. C. Q. Caracterização de lamas contendo urânio como subsídio para ações futuras de mitigação. Revista Escola de Minas, v. 64, p. 479-485, 2011.

INSTITUTO Nacional de Metrologia, Normalização e Qualidade Industrial. Orientação sobre validação de métodos analíticos (DOQ-CG-CRE-008). Rio de Janeiro: INMETRO, 2011. 20p.

KODOM, K., PREKO, K., BOAMAH, D. X-ray fluorescence (XRF) analysis of soil heavy metal pollution from an industrial area in Kumasi, Ghana. Soil and Sediment Contamination: An International Journal, v. 21, n. 8, 2012.

LACHANCE, G. R., FERNAND, C. Quantitative X-ray fluorescence analysis: theory and application. New York: John Wiley \& Sons, 1995. 424p.

LYEW, D., SHEPPARD, J. D. Effects of physical parameters of a gravel bed on the activity of sulphate-reducing bacteria in the presence of acid mine drainage. Journal of Chemical Technology \& Biotechnology, v. 70, p. 223-230, 1997.

MA, G., LIANG, G., LUO, L., ZHAN X., Li, G. Advance and function of geochemical mapping using wavelength dispersive X-ray fluorescence spectrometry in China. Advances in X-ray Analysis, v. 44, 2001.

MELQUIADES, F. L., LOPES, F., STAGNAERO, S. M., RUEDA, M., PARREIRA, P. S., APPOLONI, C. R. Chemical characterization of clay SEM by X-ray fluorescence - results comparison from diferente laboratories. Semina: Ciências Exatas e Tecnológicas, v. 30, n. 2, p. 145-150, 2009.

NATGAA, N., BUENO, M. I. M. S. Métodos matemáticos para correção de interferências espectrais e efeitos interelementos na análise quantitativa por fluorescência de raios-X. Quimica Nova, v. 24, p. 531-539, 2001.

NÓBREGA, F. A., LIMA, H. M., LEITE, A. L. Análise de múltiplas variáveis no fe- 
chamento de mina: estudo de caso da pilha de estéril BF-4, Mina Osamu Utsumi, INB Caldas, Minas Gerais. Revista Escola de Minas, v. 61, p. 197-202, 2008.

ROUSSEAU, R. M. Detection limit and estimate of uncertainty of analytical XRF results. The Rigaku Journal, v. 18, n. 2, p. 33-47, 2001.

SALOMONS, W. Environmental impact of metals derived from mining activities: processes, predictions, prevention. Journal of Geochemical Exploration, v. 52, p. 5-23, 1995.

SCAPIN, M. A., SALVADOR, V. L., COTRIM, M. E. B., PIRES, M. A. F., SATO, I. M. Uncertainty measurement evaluation of WDXRF and EDXRF techniques for the $\mathrm{Si}$ and $\mathrm{U}_{\text {total }}$ determination in $\mathrm{U}_{3} \mathrm{Si}_{2}$ used as nuclear fuel material. Journal of Radioanalytical and Nuclear Chemistry, v. 287, p. 807-811, 2011.

SCAPIN, M. A. Estudos de remoção de elementos inorgânicos e degradação de compostos orgânicos por radiação gama em óleos lubrificantes usados. São Paulo: Universidade de São Paulo, 2008. 116 p. (Tese de Doutorado em Tecnologia Nuclear - Materiais).

SCAPIN, M. A. Aplicação da difração e fluorescência de raios X (WDXRF): ensaios em argilominerais. São Paulo: Universidade de São Paulo, 2003. 80p. (Dissertação de Mestrado em Tecnologia Nuclear - Materiais).

SIMA, M., DOLD, B., FREI, L., SENILDA, M., BALTEANU, D., ZOBRIST, J. Sulfide oxidation and acid mine drainage formation within two active tailing impoundments in the Golden Quandrangle of the Apuseni Mountains, Romania. Journal of Hazardous Materials, v. 189, n. 3, p. 624-639, 2011.

Received: 20 September 2018 - Accepted: 8 July 2019. 